\title{
The Development of Vocational Agriculture before the Vocational Education Act 1963
}

\author{
Michael J. Martin ${ }^{\mathrm{a}}$, Tracy J. Kitchel ${ }^{\mathrm{b}}$ \\ ${ }^{a}$ Colorado State University, ${ }^{b}$ The Ohio State University
}

Agricultural education programs are experiencing pressure to change from a variety of educational and societal influences. This pressure is not new to agricultural education programs. The evolution of vocational agriculture from 1945 to 1963 provides a historical example of vocational education change as a result of social influences. Rural America experienced unprecedented emigration after World War II. The loss of students from farming families, the intended recipients of vocational agriculture, should have hampered local programs, but in fact the opposite occurred: enrollment in vocational agriculture continued to grow. We examine how vocational agriculture teachers transformed local programs to match their emerging clientele before the Vocational Education Act of 1963.

Keywords: history of agricultural education, vocational education change, rural communities, supervised agricultural experiences, Vocational Education Act 1963

Pressure from a variety of social and educational policy factors has stressed local agricultural education programs, which must find a fit in schools and state curriculum plans that prioritize academic rigor, standardized testing, and college entry. Agricultural education has experienced these pressures to change numerous times over the past century. External influences often precede large vocational education policy initiatives, such as the Smith-Hughes National Vocational Act of 1917 and the Carl D. Perkins Vocational and Technical Education Act of 1984 (Kliebard, 1999). These legislative acts fundamentally changed the mission and practices of local vocational education programs, but top-down policy initiatives have not been the only source of educational change for vocational education programs. Some local agricultural education programs have responded to external pressures with innovative ideas and practices meant to influence both regional and state agricultural education practices. Program changes initiated by vocational agriculture teachers from 1945 to 1963 provide an example of bottom-up educational change.

The evolution of vocational agriculture, the term for agricultural education before 1989, has value as a historical example of vocational educational change. Many vocational 
agriculture teachers and program leaders successfully adapted local programs despite powerful outside influences. In 1940, over 30 million people lived in rural communities and $53 \%$ of rural residents (15.9 million) lived on operational farms. Stimulated after World War II by a revolution in agricultural production methods (i.e., the Green Revolution) and changes to federal policies (Theobald, 1997), rural America experienced a massive emigration in the mid-twentieth century; by 1970, only 9.7 million people lived in rural communities, with $18 \%$ of those $(1.7$ million) residing on functioning farms (Danbom, 1995). The consequences of these trends reverberated through rural communities.

Male students from rural farm populations were the traditional clientele for vocational agriculture programs (True, 1929), which should have been hampered by the loss of their intended students. However, the opposite proved true; the number of students enrolled in vocational agriculture courses continued to grow, from 66,000 in 1924 to nearly 462,756 by 1961 (Panel of Consultants on Vocational Agriculture, 1964; True, 1929).

A partial answer to the question of motives was how the Future Farmers of America (FFA) was formed. With the help of the FFA, vocational agriculture programs became important components of rural schools and communities by the end of the 1950s (DeYoung $\&$ Theobald, 1991). FFA membership had increased to almost 400,000 members in over 8,000 schools by 1962 (Roberts, 1965). However, FFA growth alone does not explain how vocational agriculture adapted to meet the needs of a changing rural America. The FFA was focused on male students planning to enter production agriculture upon graduation. Further, the FFA was only for students enrolled in vocational agriculture courses. These two important operationalized conditions of the Smith-Hughes Act created roadblocks for non-farm kids taking vocational agriculture courses.

Considering the status of agriculture and the context of rural America in the 1950s and 1960s, how did vocational agriculture teachers and stakeholders adapt and maintain growth? This study explored changes in vocational agriculture education in response to demographic, economic, and political changes in rural communities from 1945 to 1963.

\section{Literature Review}

The agricultural production boom of the Green Revolution led to rural migration during the middle of the twentieth century. Agricultural production increased dramatically throughout the 1950s and 1960s (Danbom, 1995), stimulated by new technology and innovation such as seed hybrids, tractors, combines, chemicals, and improved breeding programs (Heady \& Heer, 1961) and by federal policies such as the Agricultural Adjustment Act and Conservation Commodity Corporation (Drache, 1976). These forces caused smaller farms to fail and medium-sized farms to flourish (Berry, 1977; Heady \& Hoffman, 1961; Sheppard, 1962). The resulting increase in agricultural production could be expressed in terms of a loss of agricultural labor, as the labor force lost 14 million production farmers, who presumably went to work in rural towns or left for urban centers (Danbom, 1995; Theobald, 1997).

While some individuals, corporations, and businesses profited from the agricultural boom and rural migration to towns and larger communities where there were jobs, rural 
America suffered. Small rural schools consolidated to increase enrollment and save money (DeYoung \& Theobald, 1991). Rural community institutions, such as the church, waned as communities became depopulated (Mitchell, 1962). Tax revenues dropped as businesses and people left rural communities (Paulsen \& Carlson, 1961). The trend of farms becoming bigger resulted in social polarization between the well-off and the working poor (Gardner, 2002; Goldschmidt, 1978). Wendell Berry (1977) characterized the agricultural revolution as disastrous, observing, "What we have called agricultural progress has, in fact, involved the forcible displacement of millions of people" (p. 41). Institutions in evolving or dying rural communities had to adapt. One such affected institution at the community level was vocational agriculture, which depended on the interests of the agricultural industry and the disappearing farmers.

The Smith-Hughes Act required schools to teach vocational agriculture to youth planning to enter farming. This act dissuaded the teaching of general agriculture, which included any topic not directly related to production farming, such as agricultural marketing and ornamental horticulture. The overwhelming predominance of boys in vocational agriculture programs was a product of how the policies of the Smith-Hughes Act were interpreted by the state leaders who certified and funded local programs (Hillison, 1999). The focus on vocational training of male future farmers, or farm boys, proved significant. Male students who did not want to or did not have the resources to enter production agriculture upon graduation, or town boys, were not encouraged to enroll. Females were expected to enroll in home economics and were usually excluded from vocational agriculture (Hillison, 1998; True, 1929). The legislation also required vocational agriculture students to carry out farming programs to build their expertise in agriculture (True, 1929). These farming programs were home-farm projects in which students conducted production farming enterprises of their own. These policies solidified the rural, production-oriented nature of vocational agriculture.

\section{Purpose and Research Question}

This study explores changes in vocational agriculture programs in response to demographic, economic, and political changes in rural communities from 1945 to 1963. The following research question guided this study: How did local vocational agriculture teachers transform their programs in response to the rural migration of its clientele? This historical study represents a case of educational change, providing indicators of both how education can change and how agricultural education and vocational education, specifically, could change in the future. The key to this historical story was how events happened, not what happened.

\section{Conceptual Framework}

The increase in student enrollment in vocational agriculture was partially due to vocational agriculture teachers' ability to adapt their local programs to aforementioned external forces. This bottom-up reform effort followed the educational change concept outlined by Michael Fullan (2007), which centers on interactions between 
multidimensional factors, including local characteristics (bottom-up) and external factors (top-down). Stakeholders who implement educational changes that do coordinate these factors risk failure over time. Fullan's concept of educational change provides us with a conceptualization of the process that emerged during our data analysis. Many educational changes in agricultural education, which are well-documented in the literature, occurred as a result of top-down, external legislation such as the Smith-Hughes Act of 1917. However, educational changes in agricultural education that begin at the local level, or from the bottom up, are not as well documented.

\section{Methods}

We utilized historical research methods to explore vocational agriculture from the late 1940s through the early 1960s (Henry, 2006). Chains of causality were developed linking the great rural migration and developments in vocational agriculture, framed by the onset of the Green Revolution in the mid-1940s (Danbom, 1995). We identified 1963 as our end date because of the passage of the Vocational Education Act, which changed federal rules for vocational agriculture. A wide selection of data sources were read, including agricultural education books, journals, reports, and related agricultural industry magazines. We organized our notes and searched for emergent themes that could help explain how vocational agriculture teachers dealt with the issue of rural migration.

We applied numerous standards of rigor to this study. We developed credibility by using multiple sources to explain the phenomenon and related themes. We also practiced debriefing as a research team while we identified the phenomenon for further study and constructed the themes. The transferability of the phenomenon of educational change outlined in this study to other vocational education contexts was developed through the detailed descriptions of the themes (Ary, Jacobs, \& Razavieh, 2002). We avoided presentism by framing our results through the experiences of those cited in their historical contexts (Gall, Gall, \& Borg, 2007).

\section{Findings}

Accepting Town Boys in Vocational Agriculture Programs. The migration of people from farms to towns and cities developed into a serious challenge for vocational agriculture (Chase, 1955; Naugher, 1953; Nystrom, 1953). The Smith-Hughes Act established education for farm boys who planned on entering farming upon graduation. Stakeholders (e.g., agricultural education professors, industry leaders, and states' department of education staff) espoused varying opinions about how to deal with decreased enrollment of farm boys and increased enrollment of town boys. Public debate ensued throughout the 1950s. J. Coggin (1953) of North Carolina State College argued:

To enroll those students in the high school classes who are interested in farming and who have the necessary facilities, present or potential, to make a beginning and advance in farming during the high school training period 
is one way of doing a better vocational job and at the same time lighten the load of the teacher. (p. 39)

Some stakeholders agreed with keeping town boys out of agriculture programs (King, 1954; Smith, 1955a, 1955b; Wall, 1955; Watson \& Gaylord, 1959). Their arguments included two key points. First, there was great value in carrying out a production-oriented supervised agricultural experience. Students learned how to start a farm enterprise, reflect on the practice, and adapt their experience to real-life problems. Second, agriculture teachers would have difficulties teaching both general and vocational agriculture in the same program. The complete program of agriculture should have students enrolling in four consecutive years of vocational agriculture courses. If both types of agriculture courses were taught in the same program, the time spent on general agriculture courses would interrupt students' development as production farmers.

Some stakeholders argued for ignoring the operationalized rules of the SmithHughes Act and opening vocational agriculture enrollment to town boys. H. L. Schaller (1954), editor of Better Farming Methods Magazine, suggested that:

You [the agriculture teacher] should encourage town boy participation in vocational agriculture. Yes, encourage it. Some states, administrators, and teachers, I understand, prohibit town boys from taking vo-ag. But if the boys show an interest in ag, you cultivate and develop that interest. (p. 195)

This view was shared by other stakeholders in vocational agriculture (Beam, 1958; Berg, 1955a, 1955b; Bjoraker, 1958; Knox, 1955; Smith, 1959; Sutherland, 1956), who argued that not enrolling students in agriculture would inhibit the development of successful agricultural stakeholders. E. M. Juergenson (1953) of the University of California at Davis portrayed a rural America that had outpaced the operationalization of the Smith-Hughes Act, "As the field of agriculture is constantly changing and advancing, so must the emphasis in agricultural education shift to meet these new demands" (p. 17). Many future agriculturists would not have enrolled in agriculture in the 1950s and 1960s, even in rural areas, if teachers had only farm boys in their programs.

Special consideration should be given to the issue of the production-oriented supervised agricultural experience. Stakeholders recognized the problem of finding resources for every student's production-oriented experience (Tabb, 1946). To compensate for the lack of production agriculture resources, agriculture teachers began to utilize placement and non-production-oriented supervised agricultural experiences (Bollwahn, 1956; Deyoe, 1952; Gibson, 1949; Hutchings, 1949; Wooding, 1950). Some stakeholders ridiculed these types of experiences as being educationally or vocationally ineffective compared to entrepreneurial (production-oriented) experiences (Garris, 1954; King, 1954; Smith, 1955a, 1955b; Wall, 1955). The debate ultimately centered on how to fulfill the operationalization of the Smith-Hughes Act while maintaining class enrollment.

Stakeholders eventually realized that allowing town boys in agriculture classrooms was necessary to maintain high enough enrollment to justify the existence of the agriculture program (Barton, 1956; Christenson, 1956). Indeed, despite complaints, agriculture programs had to accept town boys because those students had become a significant part of rural schools' population by the 1960s. 
Agricultural Teachers Transform their Curricula. Many agriculture teachers were not just passive observers of the changes affecting agriculture and their rural communities; they actively tried to adjust their programs. While the exact number is impossible to estimate, many agriculture teachers started to work with their local communities to adjust their curricula and educate students about agriculture-related occupations. Teachers participated in agricultural career fairs, took field trips, introduced new courses and units of instruction, cooperated with the local community to establish agricultural projects, conducted community surveys, and established program advisory councils. The curriculum changes reflected the broadening of the definition of vocational agriculture by including the study of agriculture-related occupations.

Two relatively small activities that exposed agriculture students to agriculturerelated occupations were career fairs (Pruett, 1956; Schaller, 1960), field trips (Hamilton, 1960; Hoover, 1962; Hopkins, 1960) and new agriculture courses. George Chrein (1960), an agriculture teacher from Flushing, New York, instituted a career day for his students and their parents to expose students to the local opportunities of the broader agricultural businesses:

Theoretically, every day is career day for students in vocational agriculture.

Practically, we have found the career day program in agriculture a most valuable technique for getting "firsthand" information relating to advance schools of agriculture and occupational information to our students and parents. (p. 224)

Chrein's follow-up included student reflections written immediately after the career day to encourage their thinking about local occupations. Whole nonproduction agriculture courses were also being designed and taught, particularly in agribusiness (Nichols, 1956) and horticulture (Head, 1954; Oliver, 1954; Whitley, 1962).

Dodson, Louisiana, teacher Jarred Terry (1958), realized that his program was not educating his students about forestry, an important segment of the local agriculture economy:

It would seem that the task of securing a forestry laboratory for the Dodson vo-ag classes would be a simple one indeed. After all, the school is located in the leading softwood timber region of Louisiana. Then it would seem that finding trees for students use would be as easy as finding apples in Washington or potatoes in Idaho. But, the task was harder than it appeared... But, since the aim of a school is to prepare students to take their rightful place in the community, practical forestry instruction is essential. (p. 18)

The forestry unit encompassed an entire year, during which students harvested trees, planted seedlings, and constructed a pond. Other examples of agriculture programs developing curricula based on community needs and resources included units on soil management (Eames, 1950), experimental farm plots (Westergard, 1952), and home improvement (Deyoe, 1953). 
Some programs also strove to improve their communities through cooperation. A. E. Shugart (1959), an agriculture instructor in Newton, North Carolina, started a community cannery during World War II, which grew into a significant business:

Since June, 1943, we have processed and canned 484,426 cans of vegetables, fruits and meats. Our biggest volume in one year was that in $1955-1956$ with 53,350 cans and 1,330 visits by patrons. As a vocational agriculture teacher, I know no other project in which I could have been of greater service to so many people. (p. 108)

Other community businesses started by agriculture programs included cooperative seed stores (Roy \& Dale, 1960), food-curing facilities (Peterson, 1950), and communitywide educational forums (Schroeder, 1951). One interesting state-wide program, run by a local agricultural program, was the Ohio Farm Safety Program (Woodin, 1950). FFA programs across the state worked to reduce farm accidents through machine adjustments and working safety procedures. The program claimed to have reduced accidents while picking corn by $56 \%$ after just one year.

Agriculture teachers also conducted community-wide surveys to analyze the status of agriculture in the community (Drabick, 1963; Langdon, 1963). Everett Clover (1962), an agriculture teacher in Webster, Iowa, conducted one such survey to assist him in identifying the status of agriculture in the community and planning appropriate instruction. In another example, the agriculture teacher in Sicily Island, Louisiana, teamed up with the Louisiana State University Experiment Station to conduct a business survey of their community (Roy \& Dale, 1960). They found that their community needed more skilled laborers in rural towns than working for area farmers. The survey also highlighted the Sicily Island community's need for a farm supply cooperative, which the agriculture program helped to start.

Agriculture teachers also established program advisory councils to ground their agriculture programs' activities in the community. These councils provided details about agricultural practices and businesses in the community and ways agriculture teachers could access a town's employees and facilities (Albracht, 1959; Beam \& Scarborough, 1962; Hamlin, 1949; Jones, 1959). The benefit of these activities was that agriculture teacher and students connected with local agricultural practitioners and businesses. While these community-based curriculum activities began to address the educational needs of town boys, they were still at a disadvantage in production-oriented supervised agricultural experiences.

Agriculture Teachers Transform Supervised Agricultural Experiences. Declining access to farms - or, more precisely, facilities for production agriculture hampered students' ability to conduct their mandated production-oriented supervised experience. Teachers began to adapt the requirements of the experience so that town boys could also have agricultural experiences. Two types emerged as alternatives to the production experience: nonproduction (related to agriculture) and placement (working as an employee) experiences (Deyoe, 1953; Phipps, 1952). Placement and nonproduction experiences had existed before 1950, but they had been supplementary to the production 
experience, not stand-alone experiences. As farms disappeared, these experiences became the only viable choice for students.

The idea of having students conduct nonproduction experiences only, contradicting the production-oriented mandate of the Smith-Hughes Act, gained prominence during the 1950s. These types of experiences were usually limited to home and farm improvement. The FFA legitimized these nonproduction experiences by annually recognizing students with outstanding nonproduction experiences (National Conference of Head State Supervisors, 1960). By 1950, the FFA recognized top students in the areas of farm mechanics, soil and water management, farm electrification, and farm safety at the annual National FFA Convention (Tenney, 1954). Bryce Anderson of Imperial, Nebraska, was the national FFA winner of the farm and home electrification award in 1951: "When 16 years old... Bryce convinced his parents that he could save 40 percent of the cost of wiring the farmstead if he did the work himself. He wired all of the buildings on the farm" (Deyoe, 1953 , p. 225). While some students' nonproduction experiences improved their rural communities, community development through supervised agricultural experiences was not fully recognized until after 1963 (National FFA Organization, 2003).

Nonproduction supervised agricultural experiences embedded in the community could be cooperative and comprehensive. The agricultural program at Rocky Point, North Carolina, which was a segregated African American program under the direction of S. C. Anderson, conducted nonproduction experiences to improve the homes of their communities: "Many homes were constructed or remodeled, the surroundings landscaped, food produced and conserved for home use, and the general living conditions improved in other ways" (Deyoe, 1953, p. 211). The students partnered with community members to rebuild homes and construct wells, sanitary facilities, a school shop, and a schoolcommunity cannery. Some agriculture programs integrated classroom instruction, nonproduction experiences, and community development. Students of the agriculture program in Jordan, South Carolina, encouraged the adoption of new agricultural methods and improvements through course work and nonproduction experiences. Deyoe (1953) said, “... Vocational agriculture has had a large part in bringing about diversified farming with increased production of livestock, vegetables, and sweet potatoes for home use and for sale" (p. 210). These two examples demonstrate how an agriculture program could integrate nonproduction supervised agricultural experiences and community development.

The second method for increasing student participation in supervised agricultural experiences was through placement experiences, which could be divided into two types: on a school farm and with a community-based agricultural business or farm operation. School farms were popular operations, even before the Smith-Hughes Act, and prevalent across America (Ballard, 1960; Bryant, 1960; Haight, 1961; Hohman, 1961; Nicklas, 1960). Many agriculture programs still have their own farm or farmland (True, 1929; Phipps, Osborne, Dyer, \& Ball, 2008). Bert Brown (1949), the agricultural supervisor in the Olympia, Washington, area, described how the agricultural instructors of the Battle Ground agriculture program managed their school farm: 
The class program is kept flexible so that, if weather permits, a class can go to the farm on short notice. A boy learns to prune raspberries in one or two hours. A week of it would have little or no educational value (p. 62).

School farms offered opportunities for students to conduct their production experience, but the farm's coordination could be stressful for the instructor(s): “An extra burden is often placed on the teacher which results in decreased attention to individual programs of supervised farming and other important phases of the balanced program of vocational agriculture" (Deyoe, 1953, p. 322).

Teachers also found student work on local farms or agriculture businesses to satisfy the placement experience requirement, but this presented the agriculture teacher with a different type of problem, as H. T. Pruett (1956) described: "In order to do much about placement for farm experience the teacher must know a great deal about the community, the people, and where these opportunities are" (p. 221). Finding appropriate placements required a teacher to leverage community resources (Andrews, 1958; Deyoe, 1953; Hammonds, 1950).

Even in the late 1940s, teachers realized the potential benefits of placement experiences using community resources. Jamaica Plains and East Weymouth High Schools of Massachusetts, both near Boston, adapted to these types of placement experiences (Deyoe, 1949; Nelson, 1950). Over a four-year program, students of Jamaica Plains and East Weymouth agricultural programs were expected to spend their summers working with a variety of local agricultural businesses, gaining experience in marketing garden produce, poultry farming, dairy production, and greenhouse operations. This variety of experiences would be hard to duplicate in an individual student's entrepreneurial production experience, especially near Boston. These types of arrangements were popular in increasingly metropolitan states, such as Massachusetts, because up to $90 \%$ of the students did not have the home facilities for an individual production or nonproduction agricultural experience (Taft, 1960). Other states experienced some of the same trends toward placement experiences, though not at the same level (Miller, 1962).

\section{Discussion}

The congressional hearings for the Vocational Education Act of 1963 outlined some of the then-current problems of vocational agriculture: "The panel also found that vocational education programs are not preparing people for enough kinds of jobs. One study found that only 10 boys studied agriculture for every 100 males employed in that field" (Vocational Education Act of 1963, p. 39). This act attempted to rectify these issues, expanding the curricula of vocational agriculture from production agriculture to agriculture-related occupations and ending compulsory, supervised agricultural experience for all agriculture students (Phipps et al., 2008; Talbert, Vaughn, \& Croom, 2005). Yet these transformations were already taking place around the country because of the community-based efforts of vocational agriculture teachers.

The old model of production-oriented vocational agriculture existed in some schools through the 1960s. Some agriculture teachers continued to teach a production- 
oriented curriculum and required their students to complete production supervised agricultural experiences. The arguments by the stakeholders who wanted to keep vocational agriculture exclusive to farm boys still resonated in academic institutions and local programs, even after the Vocational Education Act of 1963. However, many did not ignore the need to broaden agricultural curricula to meet the demands of evolving rural students, communities, and changing agricultural economies. These program transformations occurred even given the threat of forfeiting federal funding by ignoring the operationalized rules of the Smith-Hughes Act. The rise of nonproduction and supervised placement agricultural experiences and agriculture-occupation curricula were stimulated by local community needs, not federal legislation.

The educational changes outlined in this study follow Fullan's (2007) description of permanent change: vocational agriculture teachers revised materials, developed teaching approaches related to nonproduction agriculture, and altered their beliefs about who could enroll in vocational agriculture (as did related stakeholders). The educational change began at the grassroots level and led to the top-down changes, represented by the Vocational Education Act of 1963. Vocational agriculture teachers and community members found ways to work within the Smith-Hughes Act structure or, if needed, operated outside of that structure to accomplish their goals. These changes lasted beyond 1963 and guided vocational agriculture into the 1980s.

\section{Implications}

This study demonstrates the power of bottom-up reform movements to make lasting educational changes in vocational education. The vocational education changes made at the local level predated federal changes in vocational education legislation. Importantly, those local changes were prophetic to eventual nationwide shifts in demographics, which made the transition to the Vocational Education Act of 1963 legislation smoother. Currently, local agriculture programs have been under pressure to adapt their programs to increasing academic rigor and standards. These changes have included a variety of arrangements depending on local context, including agricultural business for consumer education credit or agricultural sciences for science credit. These changes have reshaped how some local programs think about their curricula and program purpose, allowing more students to take agriculture courses and keeping programs academically relevant and viable. Our case study indicates that these innovations have a possibility of persisting as a result of their origin in bottom-up movements and being predictive to the future direction of vocational education.

\section{References}

Albracht, J. J. (1959). Activities of the Hebron vocational agriculture advisory council. Agricultural Education Magazine, 32(6), 136.

Andrews, D. W. (1958). A new twist in education - Student workshops! Better Farming Methods, 30(12), 12-13. 
Ary, D., Jacobs, L. C., \& Razavieh, A. (2002). Introduction to research in education (6th ed.). Belmont, CA: Wadsworth/Thompson Learning.

Ballard, D. W. (1960). Understanding leads to belief in the school farm. Agricultural Education Magazine, 33(3), 66-68.

Barton, P. S. (1956). Must we change our objectives? Agricultural Education Magazine, 29(6), 130-131.

Beam, H. E. (1958). Who should take vocational agriculture in high school? Agricultural Education Magazine, 31(2), 34, 44.

Beam, H. H., \& Scarborough, C. C. (1962). Local planning: A growing need in vocational agriculture. Agricultural Education Magazine, 35(1), 5-6.

Berg, G. L. (1955a). Guest editorial. Agricultural Education Magazine, 27(8), 171-172.

Berg, G. L. (1955b). The purpose of vo-ag: An editorial controversy. Agricultural Education Magazine, 27(10), 219, 233, 236.

Berry, W. (1977). The unsettling of America: Culture and agriculture. San Francisco, CA: Sierra Club Books.

Bjoraker, W. T. (1958). What's the future of vocational agriculture? Better Farming Methods, 30(9), 40-42.

Bollwahn, L. (1956). Training in non-farm agricultural occupations for young farm people. Agricultural Education Magazine, 28(7), 157, 159.

Brown, B. L. (1949). School farm becomes much used resource. Agricultural Education Magazine, 22(3), 55, 62.

Bryant, J. (1960). A strong vote for developing a school farm. Agricultural Education Magazine, 32(7), 166-167.

Chase, D. (1955). Analysis of trends in agriculture provides basis for revising educational objectives in vocational agriculture. Agricultural Education Magazine, 28(1), 18-19, 22.

Chrein, G. (1960). The career day program in agriculture. Agricultural Education Magazine, 32(10), 224-225.

Christenson, H. (1956). Will our vo-ag program keep pace? Agricultural Education Magazine, 29(6), 128-129.

Clover, E. L. (1962). A study of community farming opportunities as a basis for program planning. Agricultural Education Magazine, 35(1), 6-8.

Coggin, J. K. (1953). A forward look at vocational agriculture. Agricultural Education Magazine, 26(2), 39, 46.

Danbom, D. B. (1995). Born in the country: A history of rural America. Baltimore, MD: John Hopkins University Press.

Deyoe, G. P. (1949). Supervised farming in vocational agriculture. Danville, IL: Interstate Publishing.

Deyoe, G. P. (1952). Improving supervised farming. Agricultural Education Magazine, 24(7), 158160.

Deyoe, G. P. (1953). Farming programs in vocational agriculture. Danville, IL: Interstate Publishing.

DeYoung, A. J., \& Theobald, P. (1991). Community schools in the national context: The social and cultural impact of educational reform movements on American rural schools. Journal of Research in Rural Education, 7(3), 3-14.

Drabick, L. W. (1963). Study the whole community: There is more than meets the eye. Agricultural Education Magazine, 35(11), 253-254.

Drache, H. M. (1976). Midwest agriculture: Changing with technology. Agricultural History, 50(1), 290-302. 
Journal of Research in Technical Careers

Eames, H. F. (1950). Schools and farms are partners in Jackson County. Soil Conservation, 16(1), 17-22.

Fullan, M. (2007). The new meaning of educational change (4th ed.). New York, NY: Teachers College Press.

Gall, M. D., Gall, J. P., \& Borg, W. R. (2007). Educational researcher: An introduction (8th ed.). Boston, MA: Allyn and Bacon.

Gardner, B. L. (2002). American agriculture in the twentieth century: How it flourished and what it cost. Cambridge, MA: Harvard University Press.

Garris, E. W. (1954). Teaching vocational agriculture. New York, NY: McGraw Hill.

Gibson, J. C. (1949). Developing non-productive farming programs. Agricultural Education Magazine, 22(4), 78, 86.

Goldschmidt, W. (1978). As you saw: Three studies in the social consequence of agribusiness. Montclair, NJ: Allanheld, Osmun, and Company.

Haight, P. A. (1961), Using the school farm effectively for supervised farm work experience. Agricultural Education Magazine, 33(12), 275-276.

Hamilton, J. (1960). Assigning responsibility - Make field trips educational. Agricultural Education Magazine, 33(3), 56.

Hamlin, H. M. (1949). Agricultural education in community schools. Danville, IL: Interstate Publishers.

Hammonds, C. (1950). Teaching agriculture. New York, NY: McGraw Hill.

Head, I. (1954). Teaching under glass. Agricultural Education Magazine, 26(7), 153.

Heady, E. O., \& Heer, J. F. (1961). Why farmers produce too much. Better Farming Methods, $33(3), 9-10 \mathrm{~A}, 21,30$.

Heady, E. O., \& Hoffman, R. A. (1961). Big farmers from little ones. Better Farming Methods, $33(7), 24-25$.

Henry, A. (2006). Historical research in education. In J. L. Green, G. Camilli, P. B. Elmore, A. Skukauskaite, \& E. Grace (Eds.), Handbook of complementary methods in education research (3rd ed., pp. 333-355). Mahwah, NJ: Lawrence Erlbaum Associates.

Hillison, J. (1998). Agriculture in the classroom: Early 1900s style. Journal of Agricultural Education, 39(2), 11-18.

Hillison, J. (1999). Whatever happened to the supervisor of the Smith-Hughes man? Journal of Agricultural Education, 40(2), 55-63. https://doi.org/10.5032/jae.1999.02055

Hohman, D. (1961). Doing to learn on the school farm. Agricultural Education Magazine, 34(3), $55-56$.

Hoover, N. H. (1962). Teaching about agricultural occupations: How to begin. Agricultural Education Magazine, 32(5), 107-108.

Hopkins, H. P. (1960). Are you getting the most out of field trips? Agricultural Education Magazine, 33(3), 55.

Hutchings, A. (1949). Productive projects preferred. Agricultural Education Magazine, 22(4), 77.

Jones, R. C. (1959). Organizing and using advisory councils for vocational agriculture. Agricultural Education Magazine, 32(5), 116-118.

Juergenson, E. M. (1953). Let's bring vo ag up-to-date. Agricultural Education Magazine, 26(1), 16-17.

King, C. E. (1954). Vo-ag and general agriculture are different. Agricultural Education Magazine, 27(1), 3-4.

Kliebard, H. M. (1999). Schooled to work: Vocationalism and the American curriculum, 18761946. New York, NY: Teachers College Press. 
Knox, H. I. (1955). To serve rural youth outside of vo-ag class: The time is ripe. Agricultural Education Magazine, 27(11), 249-250.

Langdon, C. L. (1963). It might surprise you to study your community. Agricultural Education Magazine, 35(8), 185-186.

Miller, F. L. (1962). Can vo-ag serve the boy with limited opportunity? Agricultural Education Magazine, 35(4), 98-99.

Mitchell, J. B. (1962). Is rural America losing its churches? Better Farming Methods, 34(2), 14-15, 24.

National Conference of Head State Supervisors. (1960). Techniques for improving administration and supervision in vocational agriculture (Circular No. 628). Washington DC: Government Printing Office.

National FFA Organization. (2003). Blue jackets: Gold standards. Evansville, IN: M.T. Publishing.

Naugher, R. E. (1953). Keeping abreast of changes in agriculture. Agricultural Education Magazine, 26(6), 142-143.

Nelson, H. S. (1950). Summer farm placement. Agricultural Education Magazine, 22(11), 247.

Nichols, M. (1956). "Agribusanics" - Can this be one of the answers? Agricultural Education Magazine, 28(10), 224.

Nicklas, G. W. (1960). How the school farm operates. Agricultural Education Magazine, 32(8), 187-188.

Nystrom, P. E. (1953). Socio-economic changes affecting vocational agriculture. Agricultural Education Magazine, 26(6), 135, 139.

Oliver, C. (1954). Flower show has public appeal. Agricultural Education Magazine, 27(1), 5, 22.

Panel of Consultants on Vocational Agriculture. (1964). Education for a changing world of work. Washington, DC: Government Printing Office.

Paulsen, A., \& Carlson, J. (1961). Is rural Main Street disappearing? Better Farming Methods, 33(12), 12-13, 19.

Peterson, V. (1950). Jordan teaches better living through better farming programs. Better Farming Methods, 22(9), 26, 56.

Phipps, L. J. (1952). Handbook on teaching vocational agriculture. Danville, IL: Interstate Publishing.

Phipps, L. J., Osborne, E. W., Dyer, J. E., \& Ball, A. (2008). Handbook on agricultural education in public schools (6th ed.). Clifton Park, NY: Thomson Delmar Learning.

Pruett, H. T. (1956). You can assist your vo-ag students through rendering occupational guidance. Agricultural Education Magazine, 28(10), 221.

Roberts, R. W. (1965). Vocational and practical arts education. New York, NY: Harper \& Row.

Roy, P., \& Dale, S. (1960). Vo-ag leadership in community development. Agricultural Education Magazine, 33(4), 94-95.

Schaller, H. L. (1954). Guest editorial. Agricultural Education Magazine, 26(9), 195, 208-207.

Schaller, H. L. (1960). You can start a special agricultural careers day. Better Farming Methods, $32(1), 17-18,33$.

Schroeder, W. P. (1951). Using special teachers makes a community program for adults a reality. Agricultural Education Magazine, 23(8), 180-181.

Sheppard, G. (1962). Why the "big farm" trend can't be stopped. Better Farming Methods, 34(12), $10-12,27$.

Shugart, A. E. (1959). Shartown cannery is community assets. Agricultural Education Magazine, 32(5), 107-108.

Smith, W. A. (1955a). An editorial controversy-Continued. Agricultural Education Magazine, $27(10), 219$. 
Smith, W. A. (1955b). The purpose of vo-ag: An editorial controversy. Agricultural Education Magazine, 27(11), 243, 250.

Smith, W. P. (1959). Teachers, let's be honest. Better Farming Methods, 31(6), 24-25.

Sutherland, S. S. (1956). Let's quit kidding ourselves. Agricultural Education Magazine, 28(10), $219,227$.

Tabb, W. R. (1946). Developing supervised farming programs. Agricultural Education Magazine, 19(2), 51-56.

Taft, J. A. (1960). Placement for farm work experience. Agricultural Education Magazine, 33(1), 6-8.

Talbert, B. A., Vaughn, R., \& Croom, D. B. (2005). Foundations of agricultural education. Catlin, IL: Professional Educators.

Tenney, A. W. (1954). Practical activities for future farmers. Danville, IL: Interstate Publishers.

Terry, J. Y. (1958). Vo-ag forest plots. Better Farming Methods, 30(4), 18, 20.

Theobald, P. G. (1997). Teaching the commons: Place, pride, and the renewal of community. Boulder, CO: Westview Press.

True, A. C. (1929). A history of agricultural education in the United States, 1785-1925. Washington, DC: Government Printing Office.

Vocational Education Act of 1963: Hearings before the general subcommittee on education of the committee on education and labor, House of Representatives, 88th Cong. 1 (1963).

Wall, S. (1955). Changing the program of vocational agriculture. Agricultural Education Magazine, 27(11), 244, 254-255.

Watson, C. D., \& Gaylord, B. A. (1959). Who should take vocational agriculture? Agricultural Education Magazine, 32(5), 113-115.

Westergard, E. D. (1952). Experimental plot work on alfalfa varieties. Agricultural Education Magazine, 24(4), 285.

Whitley, C. M. (1962). Increasing our emphasis on horticulture in urban communities. Agricultural Education Magazine, 35(2), 50-51.

Woodin, R. J. (1950). Farmer safety campaign. Agricultural Education Magazine, 23(2), 42, 44.

Wooding, F. W. (1950). Farming programs for non-farm boys. Agricultural Education Magazine, 23(2), 42_43. 